\title{
Spectrophotometric Determination of Sulfadiazine via Diazotization and Coupling Reaction - Application to Pharmaceutical Preparations
}

\author{
Salim A. Mohammed \\ Department of Chemistry \\ College of Science \\ Mosul University
}

(Received 6/11/2012 ; Accepted 7/1/2013)

\begin{abstract}
A simple, rapid, accurate and sensitive spectrophotometric method has been developed for the quantitative determination of sulfadiazine (SDz) in both pure and its dosage forms. The method is based on diazotization of primary amine group of sulfadiazine with sodium nitrite and hydrochloric acid followed by coupling with $\gamma$-resorsolic acid (2,6dihydroxybenzoic acid) in alkaline medium of sodium hydroxide to form a yellow coloured azo dye shows a maximum absorption at $458 \mathrm{~nm}$ against reagent blank solution. Beer's law is obeyed over the concentration range of 10-300 $\mu \mathrm{g}$ of SDz / $25 \mathrm{ml}(0.4-12 \mathrm{ppm})$ with a determination coefficient $\left(\mathrm{R}^{2}=0.9998\right)$ and molar absorptivity $4.38 \times 10^{4} 1 . \mathrm{mol}^{-1} . \mathrm{cm}^{-1}$ and a relative error in the range of $0.1-0.64 \%$ and a relative standard deviation from \pm 0.27 to \pm $1.21 \%$ depending on the concentration level of SDz. The method is suitable for the determination of sulfadiazine in the presence of other ingredients that are usually present in dosage forms. The effect of organic solvents on the spectrophotometric properties of the azo dye and the composition of the resulting product have also been worked out and it is found to be 1:2 $\gamma$-resorsolic acid: sulfadiazine. The method has been successfully applied to the determination of sulfadiazine in its pharmaceutical preparations ( tablet, and burn cream ).
\end{abstract}

Keywords : Sulfadiazine, determination, azo dye, $\gamma$-resorsolic acid, spectrophotometry.
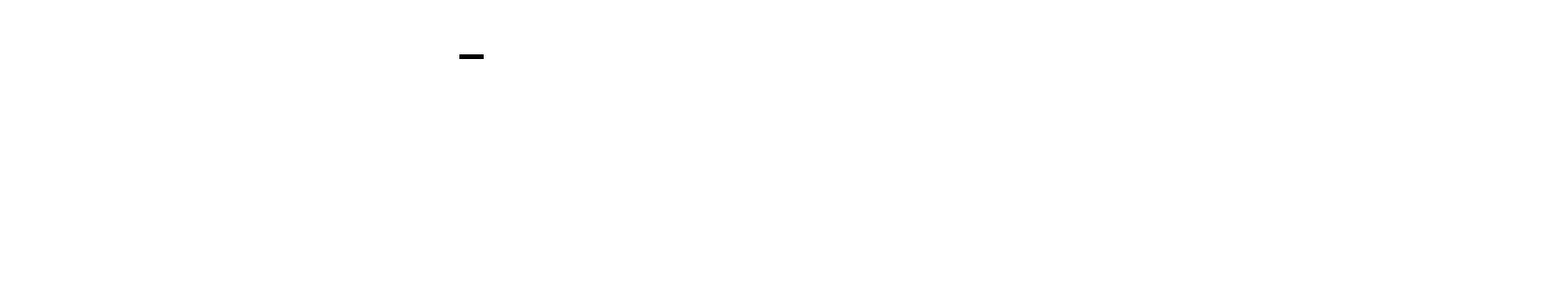

مُ قطويرطريقةطيفية بسيطة وسريعة ومسلسة لقدير ال سلفادليازين ف ي بع ـض المستح ضررات

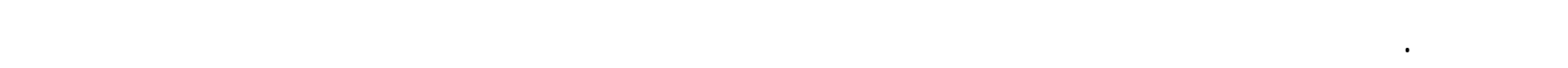

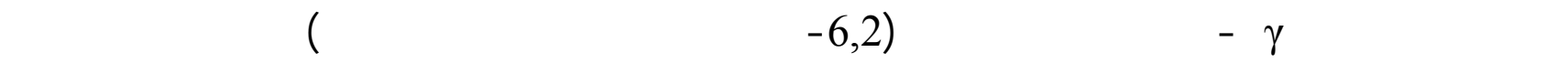

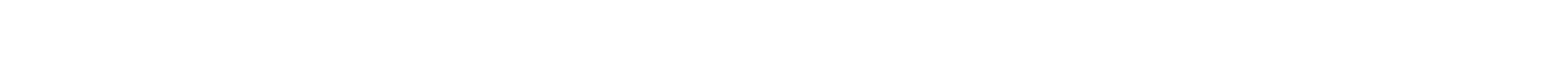

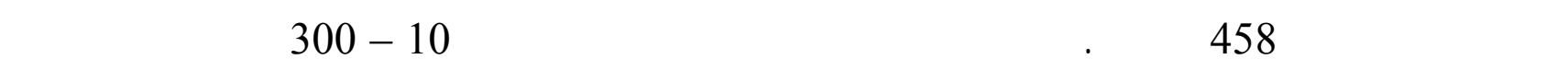

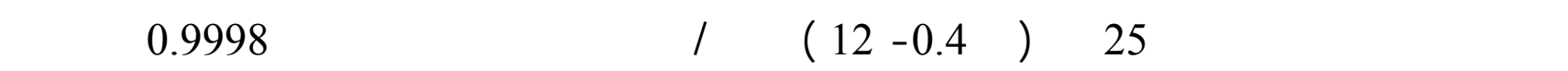




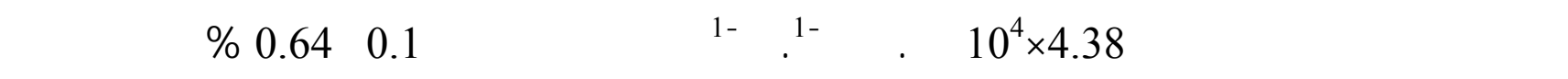

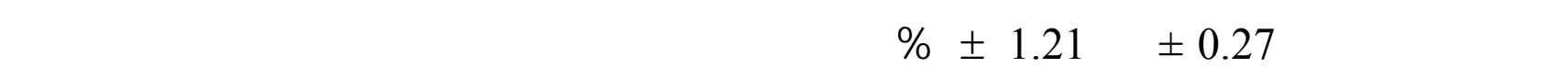

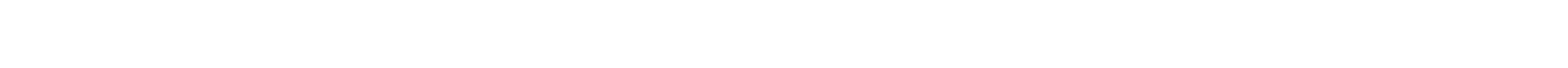
الصبغة المتكونة و أن نسبة القاعل بين المسلفادليازين و و الطريقة بنجاح لقدير اللسفادليازين في مراهم معالجة حروق الجلد فوني الأفراص الدوائية.

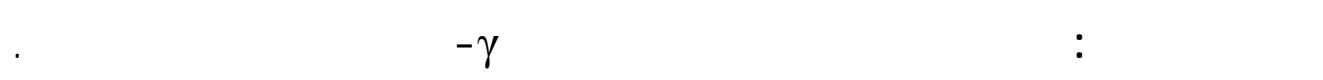

\section{INTRODUCTION}

Sulfadiazine (SDZ), 4-amino-N-pyrimidin-2-yl-benzenesulfonamide, is a sulfonamide group of antibiotic drug which has been used in veterinary and human therapy over 60 years (Pecorelli et al., 2004), it acts by inhibiting the production of folic acid inside the bacterial cell. Sulfadiazine is used for the treatment of urinary tract infections (Kothacota et al., 2011). Several analytical procedures for the determination of SDZ have been reported in the literature. Among them are reversed phase high performance liquid chromatography coupled with on-line atmospheric pressure chemical ionization mass spectrometry (HPLC,APCI-MS) (Combs et al.,1999), cloud point extraction /flow injection-flame atomic absorption (CPE/FI-FAAS) spectrometry (Dadfarnia et al., 2011), capillary zone electrophoresis (Berzas et al., 2001), inductively coupled plasma-atomic emission spectroscopy (ICP-AES) (Qi-Oi et al., 2010), liquid chromatography (Valentina et al., 2009), UV-spectrophotometry (Kotha-cota et al., 2011), immunochromatographic assay (Wang et al., 2007), flow injection chemiluminescence (Liu et al., 2007), ionselective electrode (Ayman et al., 2009). However, most of them suggest that the quantification of SDz in any matrix requires elaborate and sophisticated instruments which may or may not be available in every laboratory, others are time consuming or have high detection limit. Many UV-Visible spectrophotometric methods for the determination of SDz have been developed. Most of them included diazotization of SDZ and then coupling with different coupling reagents, such as : $\alpha$-naphthylamine (Jing et al., 2003), 8hydroxyquinoline (Nagaraja et al., 2007) iminodibenzyl (Nagaraja et al., 2002), histidine (Nabeel and Raeeid, 2006). Other methods are either based on the formation of charge transfer complex with alizarin derivatives (Amin et al., 1995), and with phenosa-phranine (Al-Attas, 2003) or an oxidative coupling reaction of SDZ with 4-amino-N,Ndimethylaniline in the presence of dichromate (Al-Abachi and Al-Talib,1995), N,N-diethylp-phenylenediamine sulphate and $\mathrm{KIO}_{4}$ (Nagaraja et al., 2010). In the present study, we succeeded in developing a new coupling agent for a sensitive and selective spectrophotometric determination of the sulfonamide based on the coupling of diazotized SDZ with $\gamma$-resorsolic acid to form a yellow colored product in alkaline medium that has been proved successfully for the determination of SDZ in both pure form and its pharmaceutical preparations. 


\section{Apparatus}

\section{EXPERIMENTAL}

All absorption spectra are carried out by a Shimadzu UV-160 double beam UV-visible spectrophotometer (Japan) with 1.0-cm silica cells while a single beam Unico 1100 spectrophotometer with $1.0-\mathrm{cm}$ plastic cells is used for absorbance measurements. The $\mathrm{pH}$ measurements are made with a Professional Benchtop pH meter BP3001.

\section{Reagents}

All chemicals used are of analytical grade.

Sulfadiazine solution (100 $\boldsymbol{\mu g} / \mathbf{m l})$. It is prepared by dissolving $0.01 \mathrm{~g}$ of SDZ in $5 \mathrm{ml}$ of ethanol and the volume is completed to $100 \mathrm{ml}$ with distilled water in a volumetric flask. The solution is then transferred to a dark bottle and it is stable for at least one week. Working solution of SDZ is prepared by an appropriate dilution of the stock solution with distilled water.

$\gamma$-Resorsolic acid $(\mathbf{0 . 1 \%} \mathbf{w} / \mathbf{v})$ solution. This solution is prepared by dissolving $0.1 \mathrm{~g}$ of $\gamma$-resorsolic acid reagent (Fluka) in $100 \mathrm{ml}$ distilled water using a volumetric flask. This solution is then transferred to a brown bottle, where it is stable for at least one week .

Sodium nitrite $(\mathbf{1 \%}, \mathbf{w} / \mathbf{v})$ solution. This solution is prepared by dissolving $1.0 \mathrm{~g}$ of sodium nitrite $(\mathrm{BDH})$ in $100 \mathrm{ml}$ distilled water.

Sulfamic acid (3\%, w/v) solution. It is prepared by dissolving $3.0 \mathrm{~g}$ of sulfamic acid (Fluka) in $100 \mathrm{ml}$ distilled water.

Solutions of $1 \mathrm{M} \mathrm{NaOH}$ and $1 \mathrm{M} \mathrm{HCl}$ are also prepared.

\section{General procedure and calibration graph}

An aliquot of sample solution containing 10-500 $\mu \mathrm{g}$ of SDZ is transferred into a series of $25 \mathrm{ml}$ calibrated flasks. To each flask, $0.5 \mathrm{ml}$ of $1 \mathrm{M} \mathrm{HCl}$ solution and $0.5 \mathrm{ml}$ of $1 \%$ sodium nitrite solution are added. The reaction mixtures are allowed to stand for $1 \mathrm{~min}$ then $1 \mathrm{ml}$ of $3 \%$ sulfamic acid solution is added and mixed thoroughly with 1 min as standing time to remove the excess of nitrite. A $0.5 \mathrm{ml}$ of $0.1 \% \gamma$-resorsolic acid solution with 1 min reaction time and $1 \mathrm{ml}$ of $1 \mathrm{M} \mathrm{NaOH}$ are then added. The contents are mixed well and diluted to the mark with distilled water. The absorbance of the formed colored azo dye is measured at $458 \mathrm{~nm}$ against the corresponding reagent blank.

\section{Procedure for dosage forms}

For tablets $(100 \mu \mathrm{g} / \mathrm{ml})$. Two tablets $(1.0 \mathrm{~g}$ sulfadiazine $/$ tablet $)$ of the drug are weighed and crushed to powder. A $0.021 \mathrm{~g}$ of this powder which is equivalent to $0.01 \mathrm{~g}$ of SDZ is weighed and dissolved in a portion of distilled water containing 2 drops of $1 \mathrm{M}$ of $\mathrm{NaOH}$ solution. The resulting solution is then mixed well, filtered to get clear solution and diluted to $100 \mathrm{ml}$ with distilled water in a volumetric flask. Each $\mathrm{ml}$ of this solution contains $100 \mu \mathrm{g}$ SDZ.

For floumizin cream (Ag.SDZ) $(100 \mu \mathrm{g} \mathrm{Ag.SDZ/ml).} \mathrm{To} 1.0 \mathrm{~g}$ of cream (containing $0.01 \mathrm{~g}$ of Ag.SDZ), added $50 \mathrm{ml}$ ether, shake well and the mixture is transferred to a separating funnel. The Ag. SDZ is then extracted with $25 \mathrm{ml}$ of distilled water (three times). The aqueous layer is collected, filtered and diluted to $100 \mathrm{ml}$ with distilled water in a volumetric flask (USP, 1995). 


\section{Principle of the colour reaction}

\section{RESULTS AND DISCUSSION}

Under the reaction conditions, SDZ is treated with nitrite solution in acidic medium to give the corresponding diazonium salt. After the removal of residual nitrite (as nitrous acid) with sulfamic acid, the diazotised sulfadiazine is then coupled with $\gamma$-resorsolic acid as a coupling agent in a basic medium to form an intensely coloured azo dye (scheme 1):
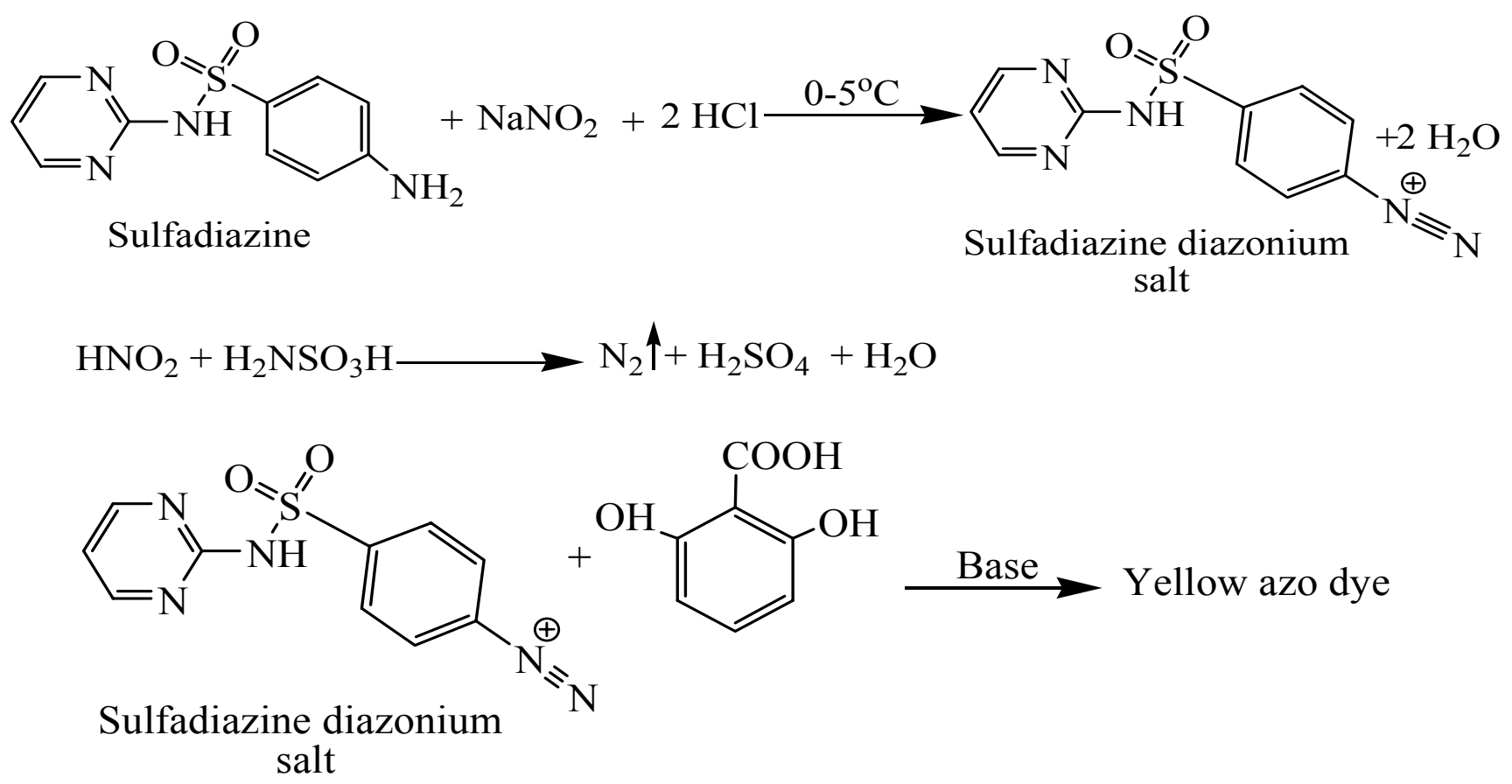

\section{Scheme 1}

The formed coloured dye exhibits absorption maxima at $458 \mathrm{~nm}$ against reagent blank. The intensity of the formed dye has been found to be proportional to the amount of SDZ originally present in the solution.

\section{Study of the optimum reaction conditions}

The effect of various parameters on the absorption intensity of the coloured azo dye is investigated and the optimum reaction conditions have been selected.

\section{Effect of diazotization acid on the absorbance of azo dye}

Different amounts of various acids such as $\mathrm{HCl}, \mathrm{CH}_{3} \mathrm{COOH}, \mathrm{HNO}_{3}$ and $\mathrm{H}_{2} \mathrm{SO}_{4}$ have been studied in diazotization of SDZ for the purpose of producing intense colored dye, a strong constant colour and a lower blank value. The experimental results showed that $0.5 \mathrm{ml}$ of $1 \mathrm{M} \mathrm{HCl}$ solution is selected for the reaction because it gives high intensity for the dye with a correspondening low reagent blank absorbance.

\section{Effect of nitrite amount and time on absorbance of azo dye}

The effect of differents amounts $0.3-0.8 \mathrm{ml}$ of $1 \%$ sodium nitrite with time on the absorbance of the resulting azo dye has been studied. The results in Table (1) show that 0.5 
$\mathrm{ml}$ of $1 \%$ sodium nitrite solution with $1 \mathrm{~min}$ as a reaction time is optimum and it is recommended for the subsequent experiments.

Table 1: Effect of sodium nitrite amount and time on absorbance

\begin{tabular}{|c|c|c|c|c|c|c|}
\hline \multirow{2}{*}{$\begin{array}{c}\text { ml of NaNO} \text { solution } \\
(1 \%)\end{array}$} & \multicolumn{7}{|c|}{ Absorbance / min standing time } \\
\cline { 2 - 7 } & 0 & 1 & 2 & 3 & 4 & 5 \\
\hline 0.3 & 0.622 & 0.628 & 0.633 & 0.649 & 0.642 & 0.640 \\
\hline 0.5 & 0.662 & 0.663 & 0.653 & 0.651 & 0.604 & 0.630 \\
\hline 0.6 & 0.660 & 0.661 & 0.634 & 0.616 & 0.607 & 0.593 \\
\hline 0.7 & 0.620 & 0.604 & 0.569 & 0.600 & 0.641 & 0.601 \\
\hline 0.8 & 0.583 & 0.541 & 0.569 & 0.611 & 0.558 & 0.619 \\
\hline
\end{tabular}

\section{Effect of sulfamic acid amount and time}

The excess of nitrite should be removed by the addition of sulfamic acid solution because of high blank values. The experimental results reveal that $1.0 \mathrm{ml}$ of $3 \%$ sulphamic acid with $1 \mathrm{~min}$ as standing time can be incorporated for the development of the formed colored azo dye Table (2).

Table 2: Effect of sulfamic acid amount and time on absorbance

\begin{tabular}{|c|c|c|c|c|c|c|}
\hline \multirow{2}{*}{$\begin{array}{c}\text { mL of sulphamic } \\
\text { acid (3\%) }\end{array}$} & \multicolumn{7}{|c|}{ Absorbance / minute standing time } \\
\cline { 2 - 7 } & $\mathbf{0 . 0}$ & $\mathbf{1 . 0}$ & $\mathbf{2 . 0}$ & $\mathbf{3 . 0}$ & $\mathbf{4 . 0}$ & $\mathbf{5 . 0}$ \\
\hline 0.0 & 0.016 & 0.0165 & 0.0143 & 0.136 & 0.0109 & 0.0094 \\
\hline 0.2 & 0.164 & 0.165 & 0.161 & 0.157 & 0.149 & 0.148 \\
\hline 0.4 & 0.611 & 0.621 & 0.626 & 0.617 & 0.614 & 0.619 \\
\hline 0.6 & 0.617 & 0.624 & 0.631 & 0.636 & 0.638 & 0.635 \\
\hline 0.8 & 0.627 & 0.624 & 0.623 & 0.621 & 0.623 & 0.617 \\
\hline 1.0 & 0.665 & 0.667 & 0.636 & 0.623 & 0.619 & 0.616 \\
\hline 1.5 & 0.655 & 0.650 & 0.643 & 0.637 & 0.637 & 0.638 \\
\hline
\end{tabular}

\section{Effect of $\gamma$-resorsolic acid amount and time}

The effect of $\gamma$-resorsolic acid amount on the absorbance of the azo dye has been studied [Table (3)]. 
Table 3: Effect of $\gamma$-resorsolic acid amount and on absorbance

\begin{tabular}{|c|c|c|c|}
\hline \multirow{2}{*}{$\begin{array}{c}\text { mL } \boldsymbol{\gamma} \text {-resorsolic acid } \\
(\mathbf{0 . 1 \% )} \text { solution }\end{array}$} & \multicolumn{3}{|c|}{ Absorbance / min standing } \\
\cline { 2 - 4 } & $\mathbf{0}$ & $\mathbf{1}$ & $\mathbf{3}$ \\
\hline 0.25 & 0.445 & 0.465 & 0.458 \\
\hline 0.5 & 0.709 & 0.701 & 0.669 \\
\hline 1.0 & 0.669 & 0.666 & 0.624 \\
\hline 1.5 & 0.659 & 0.626 & 0.611 \\
\hline 2.0 & 0.573 & 0.552 & 0.561 \\
\hline
\end{tabular}

The results in Table (3) indicate that $0.5 \mathrm{ml}$ of $0.1 \% \gamma$-resorsolic acid and $1 \mathrm{~min}$ of reaction time is more suitable to give the highest intensity value for the azo dye.

\section{Effect of base}

The preliminary investigations showed that the coupling of $\gamma$-resorsolic acid with diazotized SDZ to produce the coloured azo dye is possible only in a basic medium. Therefore, different amounts 1-3 $\mathrm{ml}$ of $1 \mathrm{M}$ solutions of various bases have been examined for the purpose of producing intense colored dye with lower blank values. The results in Table (4) indicate that the formation of the colored azo dye needs a strong basic medium. Sodium carbonate and sodium bicarbonate exhibit a weak colour contrast which is apparently due to $\mathrm{pH}$ variation. Therefore, $1 \mathrm{ml}$ of $1 \mathrm{M} \mathrm{NaOH}$ solution has been recommended for the subsequent experiments.

Table 4: Effect of base on absorbance

\begin{tabular}{|c|c|c|c|c|c|}
\hline \multirow{2}{*}{$\begin{array}{c}\text { Base used } \\
\text { (1M) Solution }\end{array}$} & \multirow{2}{*}{ Variable } & \multicolumn{4}{|c|}{ Absorbance / ml of base added } \\
\cline { 3 - 6 } & & $\mathbf{1}$ & $\mathbf{1 . 5}$ & $\mathbf{2}$ & $\mathbf{3}$ \\
\hline \multirow{2}{*}{$\mathrm{NaOH}$} & $\mathrm{A}^{*}$ & 0.711 & 0.708 & 0.697 & 0.589 \\
\cline { 2 - 6 } & $\mathrm{pH}$ & 11.48 & 12.01 & 12.25 & 12.44 \\
\hline \multirow{2}{*}{$\mathrm{Na}_{2} \mathrm{CO}_{3}$} & $\mathrm{~A}$ & 0.370 & 0.446 & 0.448 & 0.446 \\
\cline { 2 - 6 } & $\mathrm{pH}$ & 9.5 & 9.85 & 10.02 & 10.18 \\
\hline \multirow{2}{*}{$\mathrm{NaHCO}_{3}$} & $\mathrm{~A}$ & 0.091 & 0.117 & 0.134 & 0.185 \\
\cline { 2 - 6 } & $\mathrm{pH}$ & 6.45 & 7.49 & 8.99 & 9.34 \\
\hline \multirow{2}{*}{$\mathrm{KOH}$} & $\mathrm{A}$ & 0.644 & 0.623 & 0.562 & 0.506 \\
\cline { 2 - 6 } & $\mathrm{pH}$ & 11.20 & 12.12 & 12.31 & 12.55 \\
\hline
\end{tabular}

$* \mathrm{~A}=$ absorbance

\section{Effect of surfactants}

The presence of surfactants in a colored reaction mixture solution may frequently lead to an increase in the absorbance and a shift in the wavelength to higher values. In this respect, sodium dodecyl sulphate (SDS) (anionic surfactant), cetypyridinium chloride (CPC) and cetyltrimethylammonium bromide (CTAB) (cationic surfactant) and triton x-100 (nonionic surfactant) have been introduced. The results indicated that the addition of surfactants showed no useful effect. Therefore, they were omitted in this study.

\section{Development time and stability period}

To test the effect of time on the absorbance of the colored dye at $458 \mathrm{~nm}$, the colored dye has been prepared from different amounts of sulfadiazine under the optimal 
experimental conditions, and the absorbance is measured at different intervals of time up to 60 min., the experimental results shown in Table (5) indicated that the colored dye develops immediately and the absorbance remains maximum and constant for at least 60 minutes.

Table 5: Effect of time and concentration on absorbance

\begin{tabular}{|c|c|c|c|c|c|c|c|c|c|}
\hline \multirow{2}{*}{$\operatorname{SDZ}(\boldsymbol{\mu g})$} & \multicolumn{10}{|c|}{ Absorbance / min. } \\
\cline { 2 - 10 } & 0 & 5 & 10 & 15 & 20 & 30 & 40 & 50 & 60 \\
\hline $\mathbf{1 0 0}$ & 0.710 & 0.710 & 0.710 & 0.711 & 0.713 & 0.714 & 0.715 & 0.715 & 0.718 \\
\hline $\mathbf{2 0 0}$ & 1.356 & 1.356 & 1.358 & 1.358 & 1.358 & 1.358 & 1.356 & 1.358 & 1.361 \\
\hline
\end{tabular}

\section{Validity of Beer's law and reproducibility}

Under the optimum operating conditions, a linear calibration curve (Fig.1) is obtained over the concentration range of 10-300 $\mu \mathrm{g}$ of SDZ in a final volume of $25 \mathrm{ml}$ (i.e. $0.4-12$ $\mu \mathrm{g} / \mathrm{ml}$ ). Higher concentrations show a negative deviation from Beer's law. The apparent molar absorptivity of the azo dye has been found to be $4.38 \times 10^{4} 1 . \mathrm{mol}^{-1} \cdot \mathrm{cm}^{-1}$. The reproducibility of the procedure is studied by the analysis of three series of solutions (five identical samples for each series) having final SDZ concentration of $0.8,4.0,10.0 \mu \mathrm{g} \mathrm{ml} l^{-1}$. The results showed a relative standard deviation of $1.21,0.53$ and $0.27 \%$, respectively.

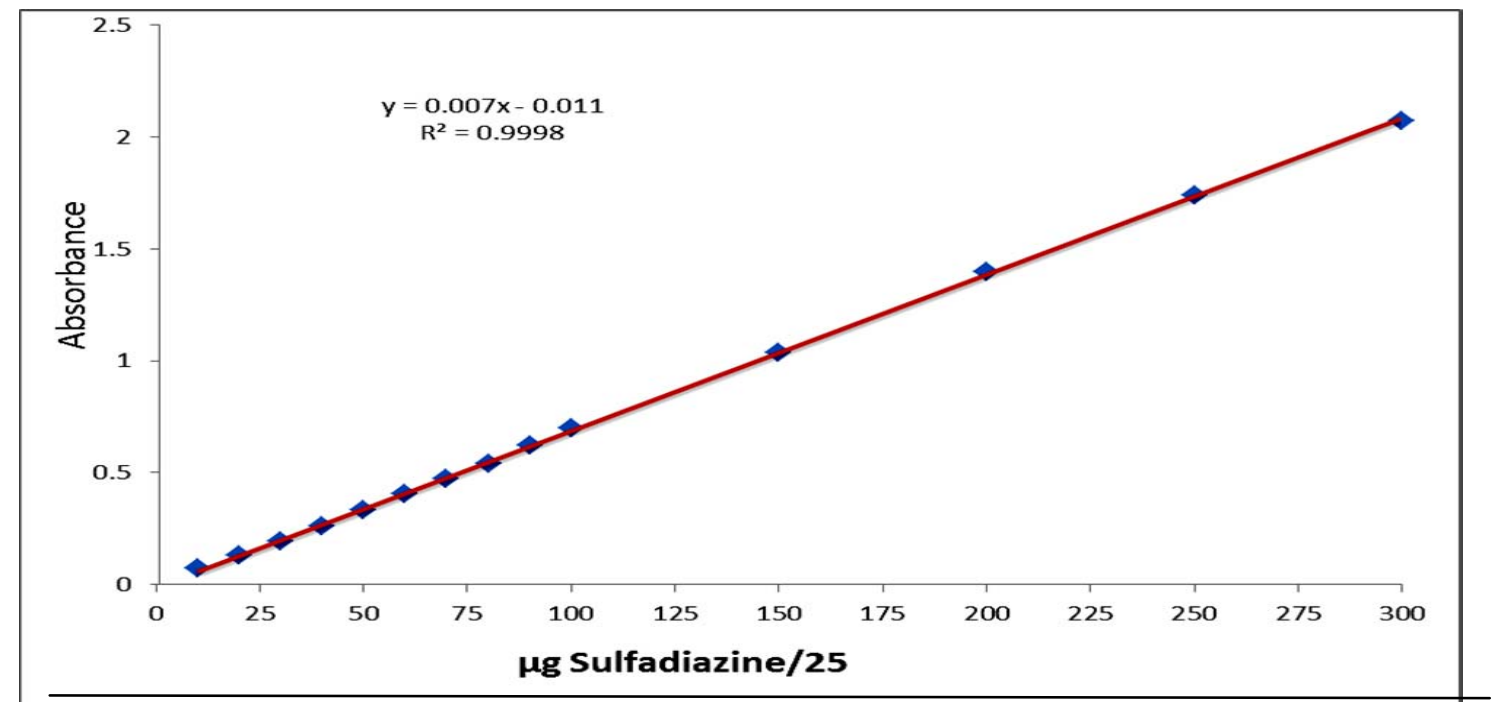

Fig. 1: Calibration curve for sulfadiazine determination , $[\gamma$-resorsolic acid $]$ : $0.1 \% ;\left[\mathrm{NO}_{2}^{-}\right]: 1 \%$ and $[\mathrm{NaOH}]: 1 \mathrm{M}$

\section{Absorption spectra}

When a dilute aqueous solution of SDZ is treated according to the optimum experimental conditions, a yellow coloured chromophore is formed immediately by coupling with $\gamma$-resorsolic acid in alkaline medium. This colored dye exhibits an absorption maxima at $458 \mathrm{~nm}$ in contrast to the colorless reagent blank which shows a negligible absorbance at this wavelength (Fig .2). 


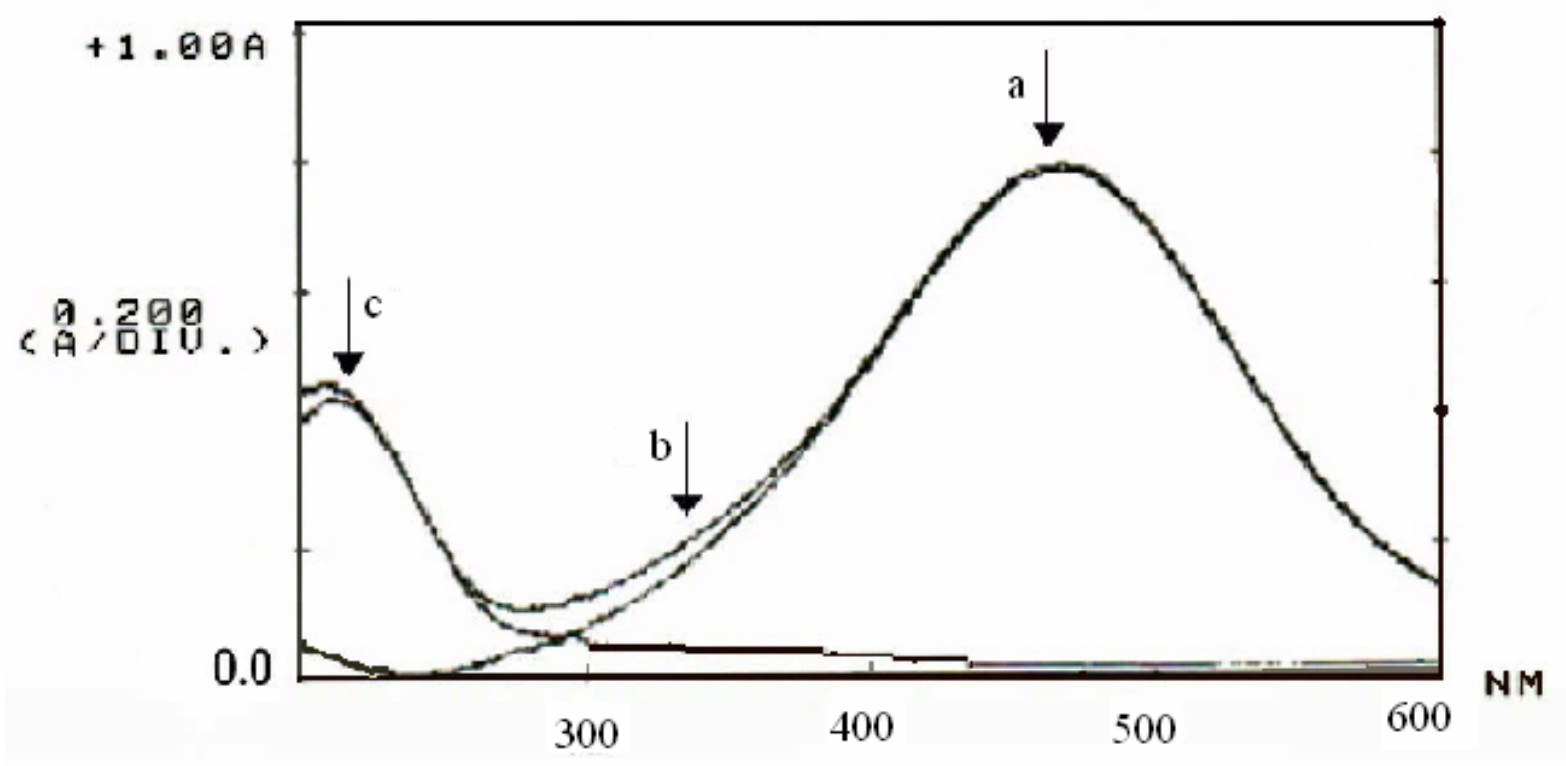

Fig. 2: Absorption spectra of $100 \mu \mathrm{g}$ of SDZ /25 ml measured against (a) blank, (b) distilled water, and (c) blank measured against distilled water.

\section{Composition of the azo dye}

The stoichiometry of the azo dye is studied under the established conditions by applying the continuous variations (Job's method) and mole-ratio methods. The experimental data in both methods (Fig. 3a and 3b) show that the azo dye has been formed by a 2:1 combining ratio of diazotized SDZ to $\gamma$-resorsolic acid.

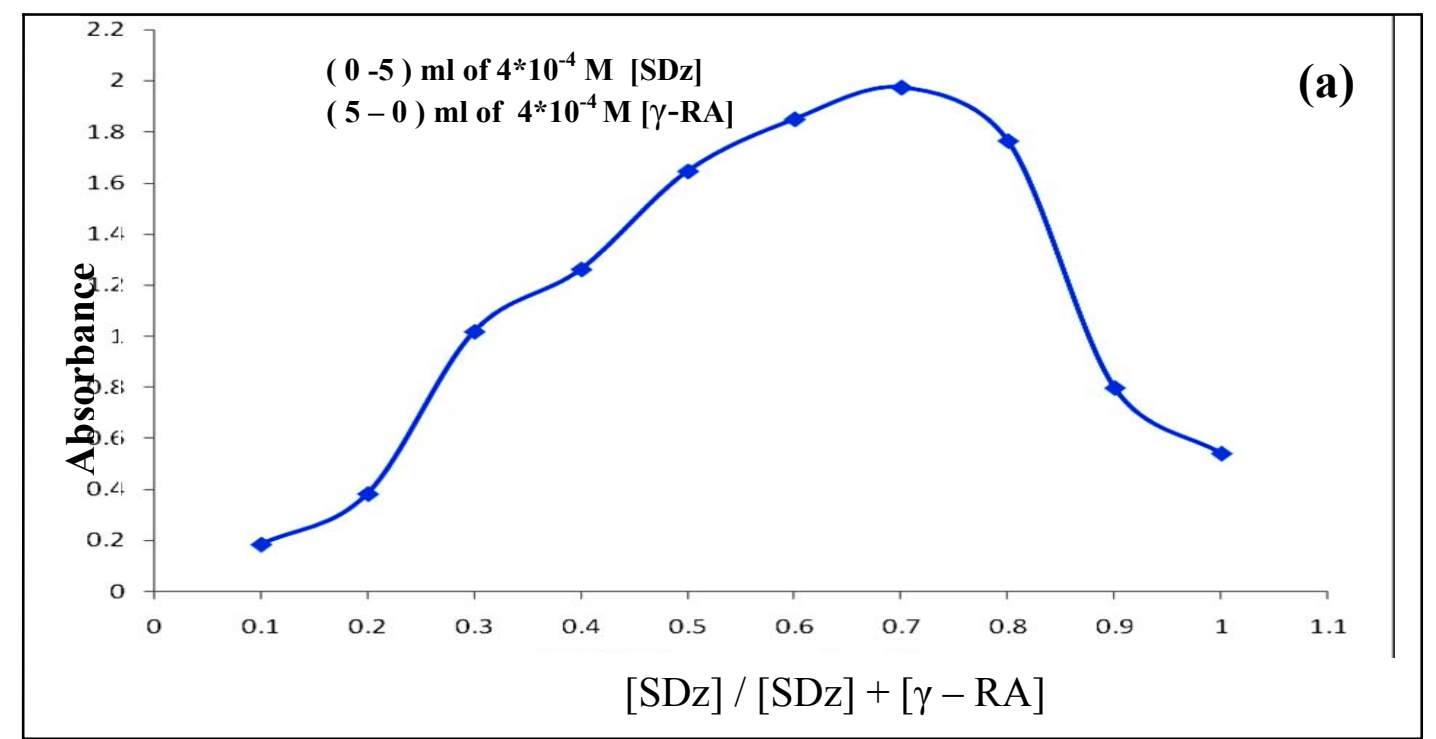




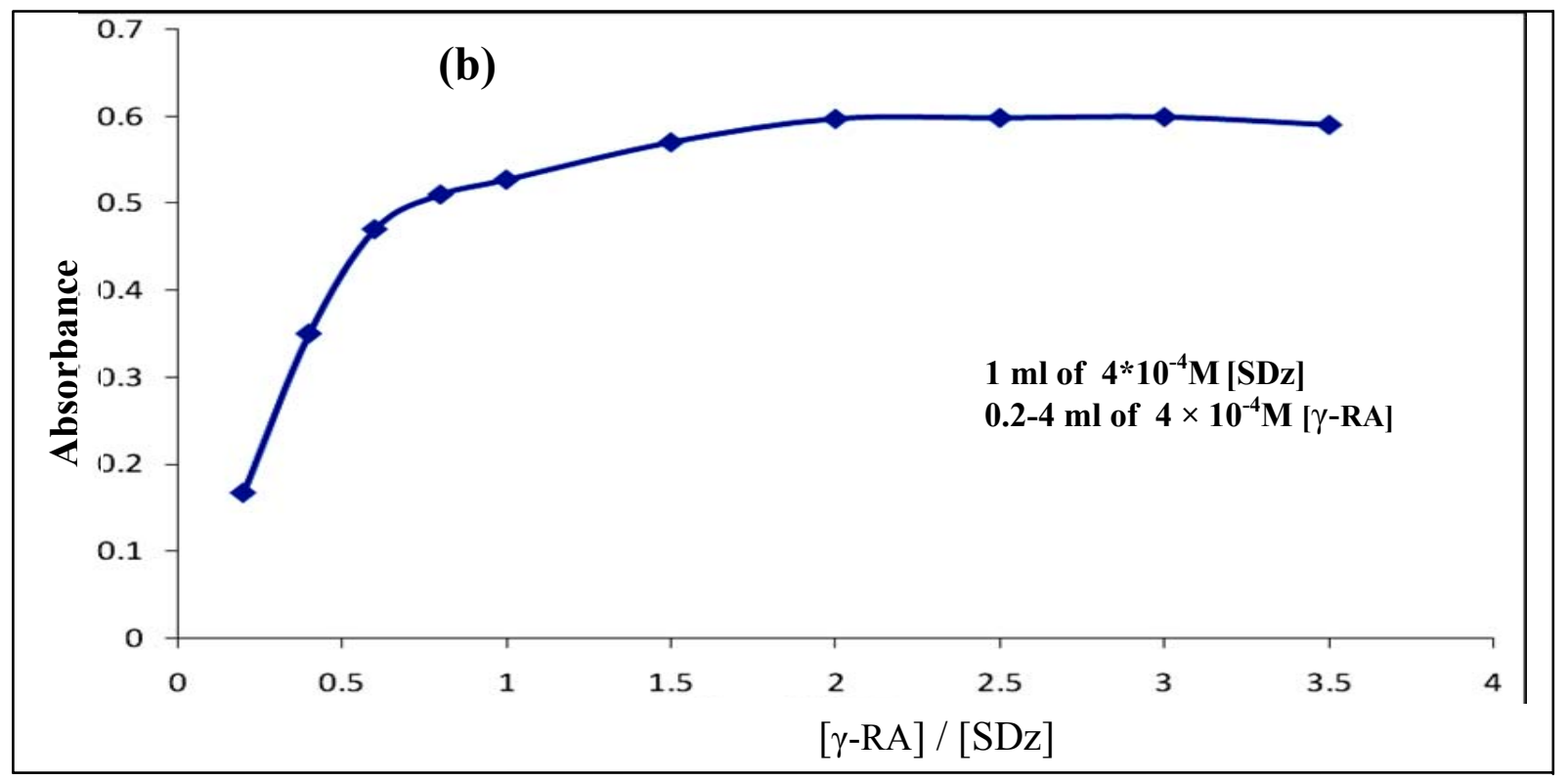

- $\gamma$-RA : $\gamma$-resorsolic acid

Fig. 3 : (a) Continuous variations and (b) mole-ratio plots for SDZ $-\gamma$-resorsolic acid

The structure of the azo dye can be written as follows :<smiles>[R]c1ccc(N=Nc2cc(N=Nc3ccc([R])cc3)c(O)c(C(=O)O)c2O)cc1</smiles>

Yellow azo dye

\section{Effect of organic solvents}

Different organic solvents are examined to evaluate their effects on the intensity of the resulting azo dye and the data are shown in Table (6).

Table 6: Effect of water and organic solvents on the optical properties of the azo dye

\begin{tabular}{|c|c|c|c|}
\hline Solvent & $\boldsymbol{\lambda}_{\text {max }}, \mathbf{n m}$ & Absorbance & $\boldsymbol{\varepsilon}, \mathbf{l . m o l}^{\mathbf{- 1}} \mathbf{. c m}$ \\
\hline Water & 438 & 0.713 & $4.45 \times 10^{4}$ \\
\hline DMF & 433 & 0.412 & $2.6 \times 10^{4}$ \\
\hline Methanol & Turbid & Turbid & - \\
\hline Ethanol & 435 & 0.701 & $4.38 \times 10^{4}$ \\
\hline Acetone & Turbid & Turbid & - \\
\hline Formic acid & 436 & 0.465 & $2.9 \times 10^{4}$ \\
\hline
\end{tabular}


Water is still chosen in the subsequent experiments due to its availability, non-toxicity and cheap as well as being a suitable medium from the sensitivity point of view.

\section{Effect of interferences}

In order to test the selectivity of the proposed method, the effect of some foreign substances (e.g., glucose, lactose, starch and gum arabic), that usually present in dosage forms are studied by adding different amounts of foreign substances to $100 \mu \mathrm{g}$ of SDZ /25 $\mathrm{ml}$. The experimental data show that the studied foreign species did not interfere in the present method as shown in Table (7).

Table 7: Effect of foreign compounds for assay of SDZ

\begin{tabular}{|c|c|c|c|}
\hline \multirow{2}{*}{ Foreign compound } & \multicolumn{3}{|c|}{$\begin{array}{c}\text { Recovery (\%)* } \\
\text { compound added }\end{array}$} \\
\cline { 2 - 4 } & $\mathbf{1 0 0}$ & $\mathbf{5 0 0}$ & $\mathbf{1 0 0 0}$ \\
\hline Glucose & 97.40 & 95.26 & 94.90 \\
\hline Lactose & 97.00 & 97.44 & 98.36 \\
\hline Starch & 99.45 & 98.50 & 102.04 \\
\hline Gum Arabic & 99.31 & 99.72 & 107.16 \\
\hline
\end{tabular}

* Average of five determinations.

\section{Application of the method}

The proposed method is applied to the determination of sulfadiazine in Floumizine cream (containing 1\% Ag-sulfadiazine) and in Sulfabehrood tablet (containing 1g SDz/ tablet). The results which are shown in Table 8 indicate that a good recovery is obtained.

Table 8: The recovery of SDz in pharmaceutical preparations

\begin{tabular}{|c|c|c|c|c|}
\hline $\begin{array}{c}\text { Pharmaceutical } \\
\text { preparation }\end{array}$ & $\begin{array}{c}\text { Certified value } \\
(\mathbf{g})\end{array}$ & $\begin{array}{c}\boldsymbol{\mu g} \text { SDz } \\
\text { present/25ml }\end{array}$ & $\begin{array}{c}\boldsymbol{\mu g} \text { SDz } \\
\text { found /25ml }\end{array}$ & $\begin{array}{c}\text { Recovery* } \\
(\mathbf{\%})\end{array}$ \\
\hline \multirow{2}{*}{$\begin{array}{c}\text { Floumizin, cream } \\
\text { (Syria) }\end{array}$} & $1 \%$ silver -SDz & 50 & 47.8 & 95.6 \\
\cline { 3 - 5 } & & 150 & 144 & 96.0 \\
\cline { 2 - 4 } & & 250 & 246 & 98.4 \\
\hline \multirow{2}{*}{$\begin{array}{c}\text { Sulfabehrood tablet } \\
\text { Behrood atrak (Iran) }\end{array}$} & $1 \mathrm{~g} \mathrm{SDz/tablet}$ & 50 & 51 & 102.0 \\
\cline { 3 - 5 } & & 150 & 154 & 102.6 \\
\cline { 2 - 5 } & & 250 & 248 & 99.2 \\
\hline
\end{tabular}

* Average of three determinations.

The performance of the proposed method was assessed by calculating the student's t-test. The results in Table (9) show that the calculated values of " $t$ " did not exceed the theoretical values at the $95 \%$ confidence level (Christian, 2004). 
Table 9: Determination of sulfadiazine in pharmaceutical preparations

\begin{tabular}{|c|c|c|c|c|}
\hline Pharmaceutical preparation & $\begin{array}{c}\text { Drug content } \\
(\mu \mathrm{g} / 25 \mathrm{~mL})\end{array}$ & $\begin{array}{l}\text { Drug found } \\
(\mu \mathrm{g} / 25 \mathrm{~mL})^{\mathrm{a}}\end{array}$ & $\begin{array}{l}\text { Recovery } \\
(\%) \%\end{array}$ & t-test ${ }^{\#}$ \\
\hline Floumizin cream & $\begin{array}{l}150 \\
250\end{array}$ & $\begin{array}{c}145 \pm 5.8 \\
\text { RSD }=4.01 \% \\
246 \pm 3.4 \\
\text { RSD }=1.38 \%\end{array}$ & $\begin{array}{l}96.6 \\
98.4\end{array}$ & $\begin{array}{l}1.92 \\
2.62\end{array}$ \\
\hline $\begin{array}{l}\text { Sulfabehrood tablet Behrood atrak } \\
\text { (Iran) }\end{array}$ & $\begin{array}{l}150 \\
250\end{array}$ & $\begin{array}{c}153.9 \pm 3.5 \\
\mathrm{RSD}=2.32 \% \\
248 \pm 1.7 \\
\mathrm{RSD}=0.70 \%\end{array}$ & $\begin{array}{c}102.6 \\
99.2\end{array}$ & $\begin{array}{l}2.40 \\
2.57\end{array}$ \\
\hline
\end{tabular}

a. Mean values and standard deviation .

* Average of five determinations.

\# Tabulated t-value at $95 \%$ confidence level is 2.776 for $(n=5)$.

Experimental $t$-value is calculated by $: \pm t=(x-\mu) \sqrt{ } \mathrm{N} / \mathrm{S}$ (Christian, 2004)

\section{Comparison of the methods}

Table (10) shows the comparison between some of the analytical variables for the present method with that of another literature spectrophotometric methods. The results indicate that the proposed method is more sensitive than the literature methods.

Table 10: Comparison of the methods

\begin{tabular}{|c|c|c|c|}
\hline Analytical parameters & Present method & $\begin{array}{l}\text { Literature method } \\
\text { Nabeel and Raeeid, } \\
\text { (2006) }\end{array}$ & $\begin{array}{l}\text { Literature method } \\
\text { (Mansour, 2002) }\end{array}$ \\
\hline $\mathrm{pH}$ & 12.35 & 12.45 & 3.19 \\
\hline Temperature $\left({ }^{\circ} \mathrm{C}\right)$ & $\begin{array}{c}\text { At room } \\
\text { temperature }\end{array}$ & $\begin{array}{c}\text { At room } \\
\text { temperature }\end{array}$ & $\begin{array}{c}\text { At room } \\
\text { temperature }\end{array}$ \\
\hline$\lambda_{\max }(\mathrm{nm})$ & 458 & 423 & 440 \\
\hline Coupling reagent & $\gamma$-Resorsolic acid & Histidine & Phenosaphranine \\
\hline Beer's law range (ppm) & $0.4-12$ & $0.4-9.6$ & $0.4-8.0$ \\
\hline RSD ( \% ) range & $0.27-1.21$ & $0.34-0.88$ & $0.32-2.34$ \\
\hline $\begin{array}{c}\text { Molar absorptivity } \\
\left(1 . \mathrm{mol}^{-1} \cdot \mathrm{cm}^{-1}\right)\end{array}$ & $4.38 \times 10^{4}$ & $1.75 \times 10^{4}$ & $4.3 \times 10^{4}$ \\
\hline Stability of the colour ( $\mathrm{min}$. & 60 & 60 & 60 \\
\hline Colour of the dye & Yellow & Yellow & Yellow \\
\hline Nature of the dye & $2: 1(\mathrm{SDz}: \gamma-\mathrm{RA})$ & $1: 1$ & $1: 1$ \\
\hline Application of the method & $\begin{array}{l}\text { Burn cream and } \\
\text { tablet }\end{array}$ & $\begin{array}{c}\text { Burn cream and } \\
\text { veterinary injectable } \\
\text { solution } \\
\end{array}$ & $\begin{array}{c}\text { Veterinary } \\
\text { suspension and } \\
\text { serum } \\
\end{array}$ \\
\hline
\end{tabular}




\section{CONCLUSIONS}

The developed spectrophotometric method for the assay of sulfadiazine is simple, sensitive, selective, inexpensive and exhibits a fair degree of precision and accuracy. Beer's law is obeyed over the concentration range of $10-300 \mu \mathrm{g} / 25 \mathrm{ml}$. with a molar absorptivity $4.38 \times 10^{4} 1 . \mathrm{mol}^{-1} . \mathrm{cm}^{-1}$ and a relative standard deviation of \pm 0.27 to $\pm 1.21 \%$, depending on the concentration level. The method does not involve any critical reaction conditions and can be compared favorably with other existing methods. The proposed method can serve as an alternative method for the analysis of SDZ in its pharmaceutical formulations (tablet and burn cream).

\section{REFERENCES}

Al-Abachi, M.Q. ; Al-Talib, S.M. (1995). Spectrophotometric microdetermination of some sulphonamide drugs via oxidative coupling with 4-amino-N,N-dimethylaniline and dichromate. J. Edu. Sci., 22, 172-185.

Al-Attas, A.S. (2003). Charge transfer complex formation in spectrophotometric and conductometric determination of some sulphonamides. Saudi Pharm. J., 11(3), 141145 .

Amin, A.S.; El-Sayed, G.O.; Issa, Y.M. (1995). Application of alizarin derivatives as chromogenic reagents for the spectrophotometric determination of some sulpha drugs. Microchem. J., 51, 367- 373.

Ayman, H.K. ; Sofia, A.A. ; Goreti, M. F. S.; Felismina, T.C.M. ( 2009). Sulfadiazine - potentiometric sensors for flow and batch determination of sulfadiazine in drug and biological fluids. Anal. Sci., 25, 365-371.

Berzas, N.J.J.; Castaneda, P.G.; Guzman, B.F.J. (2001). Determination of sulfamethoxazole, sulfadiazine and associated compounds in pharmaceutical preparations by capillary zone electrophoresis. J. Chromatogr., A, 918, 205-210 .

Christian, G.D. (2004). "Analytical Chemistry". 6th. ed., John Wiley and Sons, Inc., USA, pp. 90-94 .

Combs, M.T.; Ashraf-Khorassani, M.; Taylor, L.T. (1999). HPLC/ atmospheric pressure chemical ionization-mass spectroscopy of eight regulated sulfonamides. J. Pharm. Biomed. Anal., 19, 301-308.

Dadfarnia, S.; Hajishabani, A.M.; Rad, H.F. (2011). Indirect determination of sulfadiazine by cloud point extraction /flow injection- flame atomic absorption (CPE/FI-FAAS) spectrometry. J. Chin. Chem. Soci., 58, 503-508.

Jing, F.; Yahong, C.; Suling, F.; Cunling, Y.; Jianji, W. (2003). Flow injection spectrophotometric determination of sulphadiazine and sulphamethoxazole in pharmaceuticals and urine. Anal. Sci., 19, 419-422.

Kothacota, V.; Arun, K.D.; Umadevi, K.; Kishore, T.S.; Loya, H.; Kishant, K.P. (2011). Method development and validation of sulphadiazine in bulk and pharmaceutical dosage form by UV-spectrophotometric method. Intern. J. Pharm. Biolog. Arch., 2(4), 1167-1171.

Liu, H.; Ren , J.; Hao, Y.; He, P.; Fang, Y. (2007). Flow injection-chemiluminescence determination of sulfadiazine in compound naristillae. Talanta, 72, 1036.

Mansour, S.S. (2002). Spectrophotometric assay of sulphadiazine in veterinary pharmaceutical suspension and serum. Raf. J. Sci., 13(1), 127-138. 
Marczenko, Z.; Balecrzak, M. (2000). "Separation, Preconcentration and Spectrophotometry in Inorganic Analysis". Elsevier, pp. 114, 54-55, 116-118.

Nabeel, S.O.; Raeeid, M.K. (2006). Histidine as a new coupling agent for the spectrophotometric assay of sulphadiazine - application to pharmaceutical preparations. Raf. J. Sci., 17(4), 25-35.

Nagaraja, P.; Naik, S.D.; Shrestha, A.K.; Shivakumar, A. (2007). A sensitive spectrophotometric method for the determination of sulfonamides in pharmaceutical preparations. Acta Pharm., 57, 333-342.

Nagaraja, P.; Sunitha, K.R.; Vasantha, R.A.; Yathirajan, H.S. (2002). Iminodibenzyl as a novel coupling agent for the spectrophotometric determination of sulfonamides derivatives. Eur. J. Pharm. Biopharm., 53, 187- 192.

Nagaraja, P.; Shrestha, A.K.; Shivakumar, A.; Gowda, A.K. (2010). Use of N,N-diethyl-pphenylenediamine sulfate for the spectrophotometric determination of some phenolic and amine drugs . Acta Pharmaceutica Zagreb Croatia, 60(2), 217-227.

Pecorelli, I.; Bibi, R.; Fioroni, L.; Galarini, R. (2004). Validation of a confirmatory method for the determination of sulfonamides in muscle according to the European union regulation 2002/657/EC . J. Chromatogr. , A, 1032, 23- 29.

Qi-Oi, S.; Xiao-Ling, W.; Dong-Mei, L.; Di, G. (2010). Indirect determination of sulfadiazine by ICP-AES of CU precipitation. Chinese J. Pharm. Anal., 36(2), 117124.

United States Pharmacopeia on CD - ROM, 1995. The national formulary, $1456 \mathrm{p}$.

Valentina, G.; Chiara, T.; Fioroni, L.; Moretti, S.; Dusi, G.; Galarini, R. (2009). Development and validation of a confirmatory method for the determination of sulphonamides in milk by liquid chromatography with diode array detection. Anal. Chim. Acta, (1), 18-23.

Wang, X.; Li, K.; Shi, D.; Jin, X.; Xiong, N.; Peng, F.; Peng, D.; Bi, D. (2007). Development and validation of an immunochromatographic assay for rapid detection of sulfadiazine in eggs and chickens. J. Chromatogr., B, 847, 289-295. 